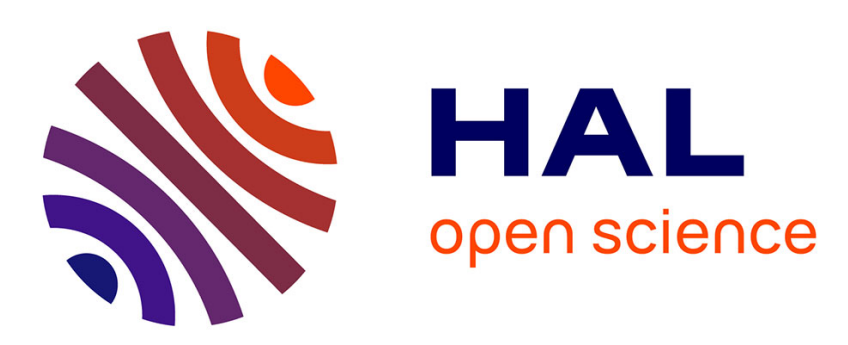

\title{
The role of legal intermediaries in the dispute pyramid: inequalities before the French legal system
}

\author{
Aude Lejeune, Alexis Spire
}

\section{To cite this version:}

Aude Lejeune, Alexis Spire. The role of legal intermediaries in the dispute pyramid: inequalities before the French legal system. International Journal of Law in Context, In press, $10.1017 / \mathrm{s} 1744552321000513$. hal-03331044

\section{HAL Id: hal-03331044 \\ https://hal.univ-lille.fr/hal-03331044}

Submitted on 1 Sep 2021

HAL is a multi-disciplinary open access archive for the deposit and dissemination of scientific research documents, whether they are published or not. The documents may come from teaching and research institutions in France or abroad, or from public or private research centers.
L'archive ouverte pluridisciplinaire HAL, est destinée au dépôt et à la diffusion de documents scientifiques de niveau recherche, publiés ou non, émanant des établissements d'enseignement et de recherche français ou étrangers, des laboratoires publics ou privés. 
Lejeune A \& Spire A (2021) The Role of Legal Intermediaries in the Dispute Pyramid: Inequalities Before the French Legal System. International Journal of Law in Context

\title{
The Role of Legal Intermediaries in the Dispute Pyramid: Inequalities Before the French Legal System
}

\author{
Aude Lejeune, CNRS, CERAPS, University of Lille \\ Alexis Spire, CNRS, IRIS, Ecole des Hautes Etudes en Sciences Sociales ${ }^{1}$
}

\begin{abstract}
This article shows that social inequalities are cumulative and occur at each stage of the dispute pyramid, from the identification of a conflict through to satisfaction with its outcome. Based on a large and original survey on ordinary people's representations of and practices within the legal system in France $(\mathrm{N}=2,660)$, our study finds that an individual's contact, or lack of contact, with a legal intermediary, who may be a legal professional or a non-legal professional, has a very significant impact on the decision to take a case to court. Contact with a legal intermediary also influences the individual's satisfaction with the outcome, but not in the same way for all plaintiffs: income is a more determining factor in satisfaction with the outcome in cases where the judge makes a decision than in cases where a solution is found outside the courtroom.
\end{abstract}

Keywords: France, Inequality, Legal Mobilization, Occupational Group, Civil Justice, Legal Intermediaries.

The literature on dispute processing has explored how ordinary citizens perceive situations as injustices, how they express grievances, and how they pursue their rights and mobilize the law. This process has been termed the "dispute pyramid," since not all injurious experiences lead to legal mobilization (Felstiner, Abel, \& Sarat 1981; Miller \& Sarat 1981; Nielsen \& Nelson 2005). However, we argue that this scholarship has not paid close enough attention to two dimensions: first, how the dispute pyramid differs depending on a set of social characteristics of the plaintiffs involved in these conflicts, and second, what factors

\footnotetext{
${ }^{1}$ Both authors contributed equally to this manuscript; their names are listed alphabetically. Corresponding author: Aude Lejeune, University of Lille-CERAPS, 1 place Déliot, 59064 Lille, France. Aude.lejeune@univ-lille.fr

Acknowledgments: This publication is part of a broader project "The Ordinary Practices and Representations of the Governed in their Dealings with the State," coordinated by Alexis Spire and supported by the French National Research Agency (ANR-15-CE28-0009). Previous versions of this paper were presented at the Law \& Society Association Annual Meeting in Washington, DC in May 2019, at the conference "Inequalities in the Practices of the Legal Institution," organized at the University of Lille in June 2019, and at the conference "Facing the State" at Columbia University Paris in January 2020. The authors gratefully acknowledge Fabien Jobard, Anna-Maria Marshall, Etienne Penissat, Cécile Rodrigues, and Susan Silbey for their useful comments on earlier drafts. We also would like to thank Sam Ferguson for his careful work in editing the text of this article prior to submission.
} 
increase or reduce inequalities among plaintiffs when they raise disputes and, in particular, what is the role played by legal intermediaries, who are primarily legal professionals (lawyers, notaries, legal advisers), but can also be non-legal professionals (trade unionists, association activists, work colleagues, etc.) (Billows, Buchter, \& Pélisse 2019).

Because of the prevalence of a "colorblind" Republican model and a deeply rooted Marxist heritage in France, social sciences have long represented society primarily in terms of social class (Bourdieu 1984). However, since the 1990s, alternative approaches have integrated ethnic origin, religion, and gender into the analysis of social and economic inequalities. These changes were influenced by various collective movements and by the adoption of several legal norms, such as the law on gender parity in 2000 (Bereni 2007) or the anti-discrimination policy of 2008 (Fassin 2002; Chapman \& Frader 2004). Gender and ethnicity have gradually become two main variables in understanding and interpreting judges' decisions, and have mostly been explored through ethnographic observation and quantitative analysis of a large number of court decisions (Collectif Onze 2013; Chappe \& Keyhani 2018; Hajjat, Keyhani, \& Rodrigues 2019; Bessière et al. 2018).

For the first time in France, this article aims to quantitatively measure inequalities among litigants at each stage of the dispute, from the identification of a conflict through to satisfaction with the outcome of this conflict. It follows the legal mobilization model, developed by Felstiner, Abel, and Sarat (1981) and by Blankenburg (1994), which identifies everyday conflicts and tracks them until the problem is considered to be resolved. However, our methodology differs from that used in many previous studies, as our statistical analysis relies on the data collected through a large and representative quantitative survey (ELIPSS panel, $\mathrm{N}=2,660$ ) on ordinary citizens' representations of and practices within the legal system in France.

The originality of the article lies in its aim to explore under which conditions the contact with legal intermediaries, both legal professionals and non-legal professionals, increases or reduces inequalities among plaintiffs when they raise disputes. Two main results can be highlighted. First, depending on their social characteristics, there are differences in the way those involved in conflicts perceive, react, and obtain satisfaction with the outcome of their conflict. Second, there is a correlation between the type of legal intermediary that people contact (a legal professional vs. a non-legal professional) and inequalities that occur among plaintiffs at each stage of the dispute process. These results are important because they demonstrate that the choice of a particular type of legal intermediary plays a crucial role in the way the legal system is used.

\section{THEORETICAL FRAMEWORK: INEQUALITIES, ACCESS TO JUSTICE, AND THE CONSTRUCTION OF DISPUTES}

Research on ordinary people's access to justice has so far developed along two main lines. The first has explored the emergence and transformation of disputes (1.1.); the second has focused on social inequalities in access to civil justice (1.2.). Our theoretical framework draws on these two approaches and is situated at the intersection of these fields in order to explore inequalities at each stage of the construction of disputes (1.3.).

\subsection{The dispute pyramid}

The first approach we build upon is that of the "dispute pyramid," which describes the emergence and the transformation of disputes as a step-by-step process 
(Felstiner et al. 1981). There are significant filters for legal action, because a disagreement can only become a legal case brought before a court if the person who experienced an offense has named, blamed, and claimed in order to pursue their rights or to redress a rights violation. Miller and Sarat (1981) made two major observations about dispute pyramids. First, the propensity to take a dispute to court depends more on the type of dispute than on the characteristics of the individual involved in the dispute, such as their race, income, or level of education. Second, the most selective stage (in the sense that most potential cases are "filtered" out) varies from one type of conflict to another: in some cases, the decision to contact (or not) a legal professional is the most selective stage, while for other types of dispute, the decision to turn to the courts is more selective.

Various studies have explored how the social characteristic of those involved in the conflicts influence legal mobilization. They have shown that some specific groups have a lower ability to assert their rights, for instance those who experience discrimination (Bumiller 1987; Clermont \& Schwab 2004), women in situations of sexual harassment (Marshall 2005), or people with disabilities (Engel \& Munger 2003; Lejeune \& Ringelheim 2019). Later, Nielsen (2000) and Morrill, Edelman, Tyson, and Arum (2010) showed that people react differently to an offense depending on their race or gender. Most of these works have criticized the pyramid model because they consider it to be too simple and too linear. Recently, the metaphor of the dispute tree (Albiston, Edelman, \& Milligan, 2014) has been developed in order to highlight the various branches or paths that a conflict can follow, some of them through legal means and others through non-legal means, with a focus on grievances that can be resolved through alternative dispute resolution. Although the dispute pyramid has been largely criticized, we consider this model to be useful for exploring inequalities in the process of legal mobilization because it allows us to explore how legal intermediaries reduce or increase inequalities among plaintiffs at each stage of this process and thus to explore unequal access to the civil legal system. However, we also take into account some criticisms addressed to this pyramid model and include a dimension that still needs to be better documented: plaintiffs' unequal satisfaction with the legal decision or the out-of-court solution.

Concerning the role of legal intermediaries, it seems useful to recall that sociolegal scholars have created this concept of "legal intermediaries" to designate actors - lawyers or non-legal professionals - who assist ordinary people in transforming their grievance into an appeal to the courts (Sarat \& Felstiner 1989; Kritzer 1990; Spire \& Weidenfeld 2011; Lejeune \& Orianne 2014; Billows, Buchter, and Pélisse 2019; Pélisse 2019; Talesh \& Pélisse 2019). A new field of research has emerged that studies the wide range of people who, although they are not legal professionals, perform the function, roles, and activities of legal intermediaries - for example, insurers (Talesh 2015), safety engineers in research laboratories (Pélisse 2017), or union delegates (Guillaume 2018a). Our theoretical approach draws on this literature, but it differs from previous works in two ways. First, we examine whether there are differences between litigants who contact a legal professional - e.g., lawyers, conciliation officers, or notaries - and those who contact a non-legal professional - e.g., trade unionists, labor inspectors, unpaid NGO activists, or street-level bureaucrats. This is particularly relevant in France, where a wide variety of legal intermediaries assist ordinary people involved in conflicts. In the case of divorces, Biland (2019) studied three types of separations which are anchored in class and gender patterns: the use of legal aid lawyers and limited adjudication for working-class couples; family mediation and out-of-court settlements for middle-class ones; and the use of private lawyers and other legal professionals to help upper-class couples to go to court. Second, instead of aiming to understand how legal intermediaries shape the interpretation 
of the law, our goal is to explore if and how their intervention produces inequalities among plaintiffs.

Concerning unequal satisfaction with the legal decision or out-of-court solution, we argue that sociolegal research has overlooked the likelihood of obtaining satisfaction with the outcome, whether inside or outside the courtroom. We consider the pyramid model to be useful for exploring how each stage of the disputes is likely to influence the plaintiffs' satisfaction with the outcome. As demonstrated by Albiston, satisfaction with a legal decision is only partially related to the content of the concerned decision. Some litigants win their case, from their lawyers' point of view, but lose it from their own perspective (Albiston 1999).

\subsection{Unequal access to civil justice}

Sociolegal studies have shown that there are very significant inequalities in access to justice based on race, gender, and social class (Sandefur 2008). Various phenomena contribute to reproducing and reinforcing inequalities in access to the civil judicial system. We will focus on three of them that are particularly relevant for our study. The first dimension is the unequal supply of legal services and legal professionals. In the 1960s, sociolegal scholars explored what they called the "unmet legal needs of the poor" (Curran 1977), arguing that legal professionals were less likely to view poor people's problems as legal issues (Carlin, Howard, \& Messinger 1966). The second dimension is unequal access to legal services and the legal system from the plaintiffs' perspective. Although class patterns have long been considered the main barrier to access to legal services and professionals, other factors might play a more significant role, such as gender (Collectif Onze 2013), unequal evaluation of the cost of a lawyer (Kritzer 2008), and legal consciousness in organizational and institutional contexts (Merry 1990; Marshall \& Barclay 2003). The third dimension is the differentiated subjective evaluation of plaintiffs' experience with the legal system. Tyler (1988) observed that satisfaction with the legal process varies according to the degree of acceptance of decisions and the degree of trust in the legal system. Other studies have criticized this approach, arguing that people evaluate the fairness of legal procedures differently depending on their social status, race, gender, or legal training (O'Barr \& Conley 1988; Greene 2016).

Two main criticisms can be addressed to these works. First, this literature has mostly focused on one particular group, but it has paid less attention to comparing differences in the conditions and opportunities of access between different groups (Sandefur 2008). Second, it has focused on instances when people have already made the decision to take their case to court and has not paid enough attention to the process that leads some people to go to court and others not to. Since the 1990s, scholars have attempted to address this question by examining how some ordinary situations are transformed, or not, into legal action (Genn 1999; Pleasence, Balmer \& Buck 2006; Pleasence, Balmer, \& Sandefur 2016). Our approach takes into account the criticisms addressed to research on unequal access to civil justice (Albiston, Edelman, \& Milligan 2014): rather than focusing on civil legal categories, we consider all situations that lay people perceive as conflicts, whether these conflicts involve, or do not involve, civil legal issues. $^{2}$

\footnotetext{
${ }^{2}$ In our approach and survey, we used the term conflict rather than grievance because the former more clearly pits the plaintiff against an opposing entity.
} 


\subsection{Under which conditions does the contact with legal intermediaries reduce or increase inequalities among plaintiffs at each stage of the dispute?}

Our research project relies on two main hypotheses. First, we explore each stage of the construction of the dispute process, in order to determine if and to what extent we observe inequalities among respondents. Throughout the process of mobilization of the law, do individuals differ in their perception of situations as conflicts, in their mobilization of legal intermediaries, and in their access to the legal system?

H1: The construction of a dispute is an unequal process at each stage, from the identification of a conflict through to satisfaction with the outcome of the conflict, depending on a set of social characteristics of the respondents.

Second, we explore under which conditions the contact with legal intermediaries reduces or increases inequalities among plaintiffs at each stage of the dispute pyramid, including the likelihood of eventually being satisfied with the outcome of the conflict - a stage that the literature on the dispute process has not taken into account. We aim to compare the differences between respondents who had been in contact with a legal professional, those who had been advised by a non-legal professional, and those who did not contact anyone to help resolve their problem.

H2: Differences in the type of legal intermediary contacted are likely to increase inequalities among plaintiffs at the different stages of the dispute pyramid.

\section{DATA COLLECTION AND ANALYSIS}

After a presentation of the survey (2.1.), we will explain the decision to focus on three types of conflict (2.2.) and the choice of the criteria used to explore inequalities in France (2.3.).

\subsection{Presentation of the survey}

Our study is based on an original quantitative survey "Practices and Representations Toward the State" which is part of the ELIPSS panel (Longitudinal Internet Studies for the Social Sciences) representative of the population living in France. Panel members were randomly selected by the French National Institute of Statistics and Economic Studies (INSEE) and provided with a touchscreen tablet and a mobile Internet subscription so that they could participate in a survey each month. The survey was administered in January 2017 to a sample of 2,970 respondents, representative of the population living in mainland France and aged between 18 and 75 years. Unlike internet opinion polls, ELIPSS includes people who do not have internet access and guarantees a much higher response rate because the panelists risk losing the tablet and internet subscription if they do not respond. With a response rate of around $90 \%$, our survey includes 2,631 respondents. By including all those who have experienced a conflict and those who have not experienced one, this method allowed us to highlight the likelihood of going to court depending on the type of conflict and the social characteristics of the people concerned.

Following the method used in previous research (Genn 1999; Miller \& Sarat 1981; Pleasence et al. 2006), we asked the respondents if they had previously experienced 
different types of conflict in their life, ${ }^{3}$ how they resolved each of them, and whether they were satisfied with the outcome of the conflict.

\subsection{Selection of three types of conflict}

The survey addressed six types of experiences of conflict that are commonly reported in France: with family members (concerning child care, inheritance, etc.); with employers or colleagues; with one's tenant or landlord; with a public service or an administration; with a neighbor; and with a private company supplying goods and services (phone operator, bank, etc.). All of these conflicts can be taken to court or resolved outside the courtroom.

Among the six types of conflict, we focused on the three most frequently reported conflicts (Figure 1). 38\% of respondents had previously had a conflict with an employer or a colleague; 31\% with a private company supplying goods and services; and 30\% with a neighbor. Respondents who had experienced these conflicts reported that they turned to the courts in 13\% of cases of a conflict with an employer or colleague; in $6 \%$ of cases of a conflict with a private company supplying goods and services; and in $4 \%$ of cases of a conflict with a neighbor. We excluded conflicts with a family member, which lead to legal action in a high percentage of cases but are less frequent among the whole population $(10 \%)$.

The three types of conflict we investigated are very different. On the one hand, conflicts with an employer or with a private company involve an asymmetrical relationship between the parties and have historically been constructed as political causes in France, where various social movements have promoted the rights of consumers in the face of large private companies (Pinto 1989) and the rights of workers in the face of their employers (Willemez 2005). On the other hand, there was no social mobilization of this kind for conflicts with a neighbor, which involve a more symmetrical relationship between the parties.

\section{Figure 1. Conflict frequency and lawsuit frequency}

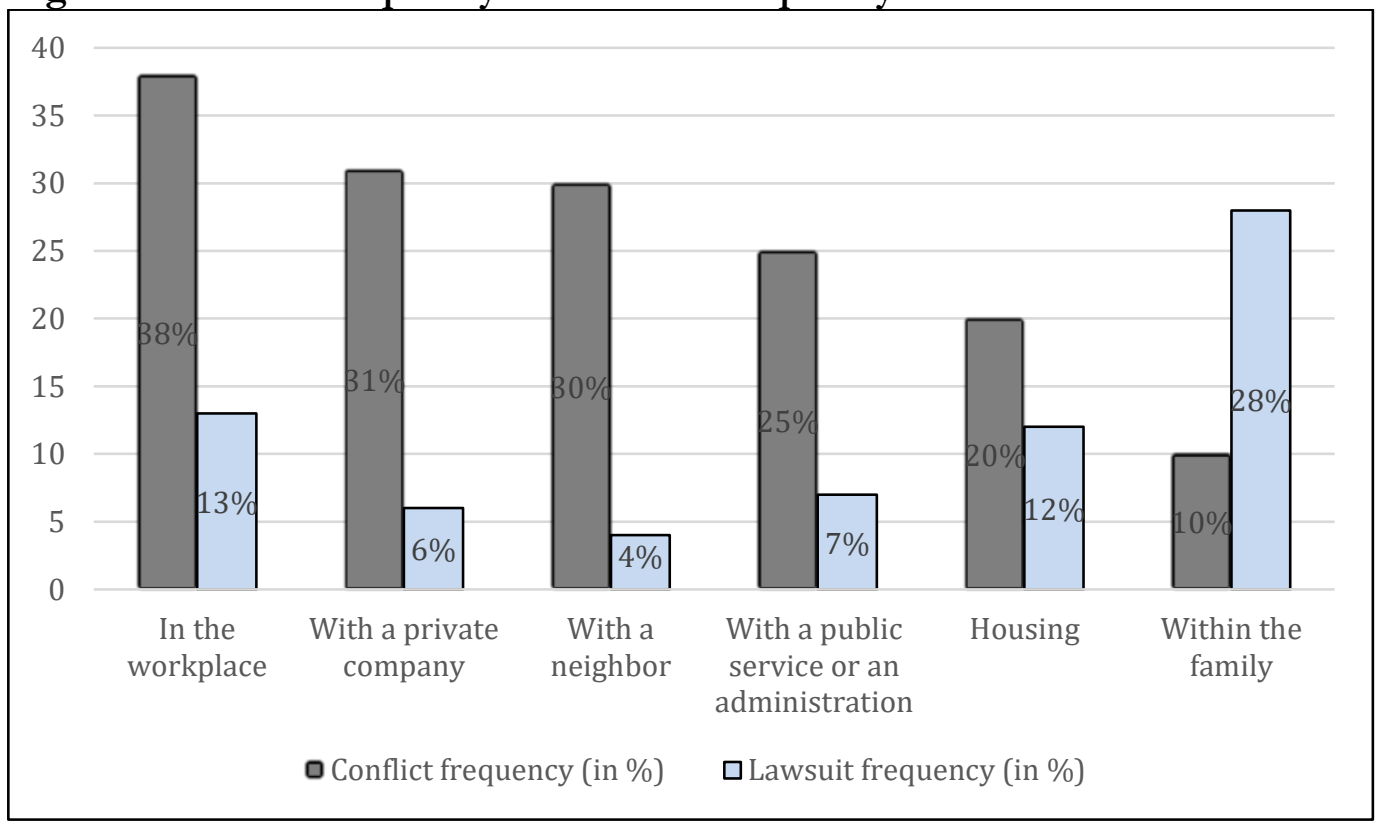

\footnotetext{
${ }^{3}$ With no time restriction.
} 
Source: PREFACE survey, “Pratiques et représentations face à l'État," January 2017 (ELIPSS/CDSP). Population: Respondents who answered the questions about conflicts ( $=2,631)$

Note: $30 \%$ of respondents had a conflict with a neighbor and, among them, $4 \%$ brought the conflict to court.

\subsection{How to measure inequalities in the context of the French legal system?}

We explore the influence of nine dimensions: gender, income, education, occupational group, context of employment, age, area of residence, nationality, and country of birth (European/non-European). Our approach slightly differs from that used in the majority of previous studies on inequalities in access to justice in three main ways.

First, in contrast with many surveys on experiences with the legal system (Genn 1999; Pleasence et al. 2006), we did not use skin color or racial self-identification to explain the formation of disputes and access to the courts. For a long time, France was considered a colorblind society in which ethnicity was not a legitimate criterion for group description. As a result, there is no official categorization of ethnic or racial groups in the national census. The two criteria used by statisticians are nationality of the respondents and their country of birth. It has recently been possible to include questions about perceived ethnicity in some surveys, but only if the authors of the research obtain authorization to collect these data by proving that information about ethnicity is crucial for their study (i.e., in studies specifically focusing on the influence of ethnicity). Because our research looked at practices and representations of the state for the whole population and thus did not focus specifically on issues related to ethnicity, we were not allowed to ask questions about race or skin color. In this context, we used the two criteria available in our data - nationality and country of birth - but both appeared to be non-significant variables in the three types of conflict, probably owing to the small number of respondents in our sample with a foreign nationality and/or born outside of Europe.

Second, we included in our analysis the occupational group variable - namely, technicians, blue-collar employees, professionals, service employees, managerial selfemployed, and agricultural workers. This criterion has always played a structuring role in defining social inequalities in France. For those who are in the active population, we used their current professional position; for those who are retired or unemployed, we used their last professional position. The relevance of the variable of professional position is not limited to the analysis of conflicts with an employer or a colleague. In France, this criterion determines distinct social practices in many different fields, such as the education system (Bourdieu \& Passeron 1990), cultural tastes (Coulangeon 2015), and food consumption (Plessz \& Gojard 2015).

Third, our survey has taken into account the context of employment - namely, the self-employed, private-sector employees, and public-sector employees - because, in France, each status involves different systems of social protection and appears to be an important criterion for comparing social groups (Hugrée, Penissat, \& Spire 2015).

\section{ANALYSIS: INEQUALITIES AT EACH STAGE OF THE DISPUTE PROCESS}

This section analyzes how inequalities are produced at each stage of the dispute process, when people identify situations as conflicts (3.1.), try to resolve these conflicts (3.2.), decide whether or not they take them to court (3.3.), and obtain satisfaction or not with the outcome of the conflict (3.4.). 


\subsection{Who experiences conflict? Inequalities at the bottom of the dispute pyramid}

The first stage in the process of legal mobilization is identifying a problem and considering it an offense or an injurious experience (naming). In order to take this stage into account in our survey, we asked questions about previous experiences of conflicts in different areas. As mentioned above, we will focus here on conflicts with employers or colleagues, with neighbors, and with private companies supplying goods and services. We consider the three types of conflict together and we explore the propensity to experience at least one of these conflicts. The logistic regression highlights the characteristics of those who do not engage in conflicts or who do not consider harm to be an injustice (Table 1).

Among the respondents, the first common trend is the difference according to gender. Women are less likely than men to perceive an experience as a conflict. This result can be explained by sexist norms of acceptable behavior for men and women; the decision to trigger a conflict is often guided by shared understandings, beliefs, and expectations about how we believe men and women should act (Davis \& Greenstein 2009: 100). We can make the hypothesis that women experience as many or even more contentious situations than men, but that they do not necessarily describe the situations as conflicts. In conflicts with employers, we can assume that, even if their rights are violated, they do not consider that they are in a position to pursue their rights because they are more likely than men to work in subordinate positions (Savage \& Witz 1992) and they are more rarely unionized (Guillaume 2018b), or because they are less likely to perceive injuries as harm. For instance, women do not often view sexual comments from male colleagues as a rights violation (Marshall 2005). However, in some situations of conflict, the gender difference is blurred. In cases of conflict with a neighbor, perhaps because these conflicts often involve the entire household instead of individuals, the gender difference is less significant than for other types of conflict.

The second common trend is the difference in the level of education. People with a low level of education are less likely to declare a conflict. The most significant difference here is in conflicts with private companies supplying goods and services: $42 \%$ of those who have an MA or MS degree (maitrise) have experienced conflicts of this kind, while only $24 \%$ of those without any qualifications have done so. Previous work has demonstrated that the companies involved in these conflicts are not the same: studies have shown that consumers at the top of the social hierarchy have more conflicts with banks and insurance companies (Pinto 1989: 72), while those with a lower level of education have more conflicts with commercial companies such as telecommunication companies. Our survey brings a new element to the analysis: it is not only the type of companies that differs depending on social position, but also the probability of experiencing a conflict with these private organizations. There is also a significant difference for conflicts with an employer or colleague. $43 \%$ of those with a baccalauréat (a high school leaving certificate at the age of 18) have experienced conflicts at work, compared to just $31 \%$ of those without any qualifications. The difference is less significant in cases of conflicts with neighbors: $34 \%$ of those with a baccalauréat have experienced this type of conflict, compared to $28 \%$ of those without one. We can assume that those who have obtained a baccalauréat and university degrees experience more conflicts because they consider that they have more legitimacy to define what a conflict is. 
We observe a third variation depending on area of residence. Respondents living in rural areas and small towns of fewer than 20,000 inhabitants are less likely to declare conflicts than others. In such cases, we can assume that it may be more costly to engage in conflict when living in a small, close-knit community: some situations between local actors may be seen as disputes and not as conflicts.

Age is also a significant factor, particularly because respondents under 29 or over 60 are less exposed to conflicts than other respondents. For those between 30 and 59, the probability of experiencing conflicts is greater. Two elements can explain this difference. First, in relation to conflicts with employers or colleagues in the workplace, people between 30 and 59 are those most likely to be in work: in France, many of those under 29 are still in training or occupy temporary positions, which makes it harder to react to labor conflicts. Second, concerning conflicts with neighbors, age is correlated to housing occupation status: among those who have experienced neighborhood conflicts, $19 \%$ of those under 29 are homeowners (and 81\% are tenants), whereas $69 \%$ of those over 29 are homeowners (and 31\% are tenants). It is between the ages of 30 and 59 that people tend to become the owners of their main homes, which can lead to conflicts related to noise, property boundaries, or lifestyle.

These variations in the propensity to name a situation as a conflict reveal that the first stage in the process of legal mobilization is related to a set of social characteristics that contribute to the feeling of being entitled to consider a dispute as a conflict. The four relevant characteristics - namely gender, level of education, area of residence, and age suggest a divide between respondents with sufficient resources to engage in a conflict and those who do not feel legitimate to place themselves in a conflict situation.

Table 1. Logistic regression on the probability of experiencing at least one conflict

\begin{tabular}{|lll|}
\hline Characteristics & Estimate & Pr $>$ chi-2 \\
Intercept & 1.1568 & $<.0001$ \\
Women & $-0.1852^{* *}$ & 0.0248 \\
Men & Ref & Ref \\
Without any qualifications & $-0.4643^{* * *}$ & 0.0012 \\
With a secondary vocational and & $-0.2809^{* *}$ & 0.0297 \\
technical qualifications (BEP) & & \\
$\begin{array}{l}\text { With a high school diploma } \\
\text { (Baccalauréat) }\end{array}$ & Ref & Ref \\
$\begin{array}{l}\text { With an undergraduate degree or BA } \\
\text { (Licence) }\end{array}$ & Ns & 0.5244 \\
$\begin{array}{l}\text { With a postgraduate degree, MA or } \\
\text { MS (Maitrise) }\end{array}$ & Ns & 0.4818 \\
Living in a rural area & $-0.3433^{* * *}$ & 0.0051 \\
Living in a town of fewer than & $-0.2731^{* *}$ & 0.0411 \\
20,000 inhabitants & & Ref \\
Living in a town of 20,000 to & Ref & \\
200,000 inhabitants & & \\
\hline
\end{tabular}




\begin{tabular}{|lll|}
\hline Living in a town of 200,000 to & Ns & 0.1532 \\
2,000,000 inhabitants & & \\
Living in Paris & Ns & 0.9398 \\
Under 29 years & $-0.5499^{* * *}$ & 0.0004 \\
30 to 39 years & Ns & 0.4026 \\
40 to 49 years & Ref & Ref \\
50 to 59 years & Ns & 0.2102 \\
Over 60 years & $-0.4110^{* * * *}$ & 0.0004 \\
\hline
\end{tabular}

Source: PREFACE survey, “Pratiques et représentations face à l'État,” January 2017 (ELIPSS/CDSP).

\subsection{The implications of respondents' first reactions to their conflicts}

Once people have identified conflicts, they may have various reactions. We now focus on the subpopulation of the 1,690 respondents who have experienced at least one conflict with a private company, with employers or colleagues, or with a neighbor: 890 have experienced one of these conflicts, 556 have experienced two of them, and 244 have experienced three of them. We distinguish four reactions: to do nothing; to manage their conflict by themselves; to get advice from a non-legal professional, such as a trade unionist, a labor inspector, a psychologist, an insurance provider, or a mediator; or to turn to a legal professional, such as a private lawyer, a conciliation officer, or a notary. These different options are of course not exclusive, and each respondent may, for the same conflict, solicit several people to advise and support them. We will highlight the influence of respondents' social characteristics on their first reaction to their conflict and on their propensity to contact legal intermediaries. We will examine in the next section how the first response shapes the decision of whether to turn to the courts.

When we consider all types of conflict together, three main criteria influence how respondents react and resolve their conflicts. The first criterion is occupational group. Respondents who work in low-paying jobs and who lack security in employment are those who most often turn to non-legal professionals to help them (a non-profit organization, a public administration, a labor union, etc.). But they make relatively little use of legal professionals. Significantly, blue-collar employees and service employees stand out from the other groups because they are those who use legal professionals the least. By contrast, respondents who work as managerial self-employed and small entrepreneurs are less frequently helped by non-legal professionals but are the most likely to seek the help of legal professionals (see Figure 2).

\section{Figure 2. The first response according to occupational group}




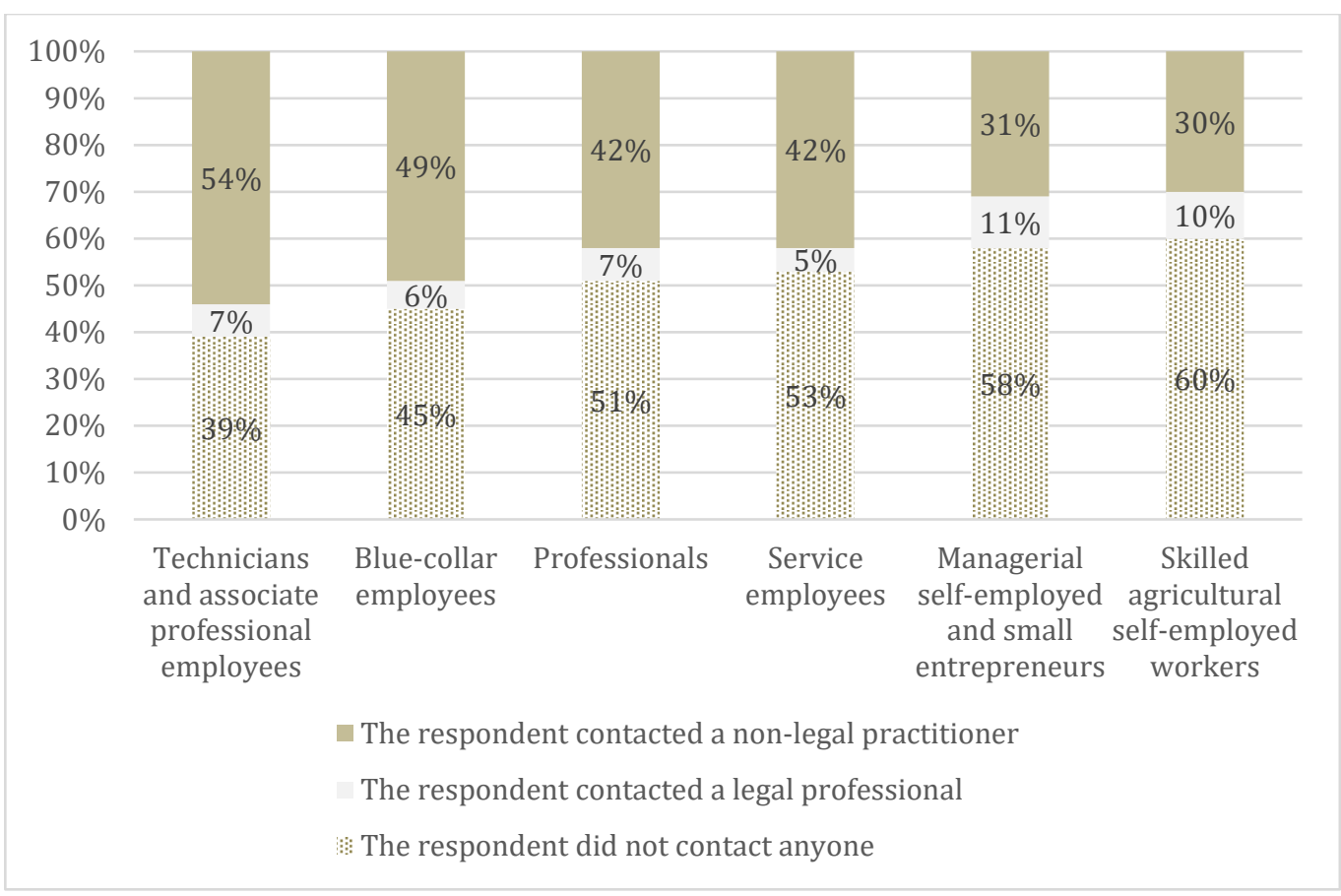

Source: PREFACE Survey, "Pratiques et représentations face à l'État," January 2017 (ELIPSS/CDSP). $\mathrm{N}=1,610$

The distinction between public-sector employees, private-sector employees, and the self-employed (context of employment) is also significant in explaining the type of intermediary the plaintiff contacted: more than half of the public-sector employees contacted a non-legal professional, whereas this was the case for $43 \%$ of the privatesector employees and only $35 \%$ of the self-employed. But when it comes to contacting a legal professional, the self-employed were much more likely to use a legal professional $(12 \%)$ than employees from the public $(7 \%)$ and private $(6 \%)$ sectors were. This difference in the propensity to contact a legal professional can be explained by the fact that the self-employed and small entrepreneurs are the most likely to have previously been in contact with a legal professional or to personally know a lawyer. In a study conducted among taxpayers, it was found that the self-employed deferred to their accountant or lawyer as soon as they had the least conflict with the tax administration (Spire 2018). Significantly, 10\% of them turn to a specialist to fill in their tax form, while only $2 \%$ of the whole population does this. Symmetrically, they are also the most likely to turn to a legal professional when they experience a conflict.

The third criterion is age. Younger respondents are less likely to turn to legal intermediaries when they face a conflict than older respondents. This is not only true for contact with a legal professional, but also for advice from a non-legal professional. Indeed, $31 \%$ of respondents under 29 turned to a non-legal professional, compared to $49 \%$ of those over 50 . Similarly, $3 \%$ of respondents under 39 turned to a legal professional to resolve their conflict, compared to $12 \%$ of respondents between 50 and 59.

When respondents experience a conflict, contact with a legal intermediary varies significantly depending on their social characteristics. We observe a clear divide between those who are networked and have had previous connections with legal professionals, namely the self-employed, managers, and small entrepreneurs, or the oldest respondents, 
and those who lack these types of resources, namely blue-collar workers, private-sector employees, and the youngest respondents.

\subsection{Going to court or finding another way to resolve a conflict}

We will now focus on who turns to the courts and who does not. As previously, we consider the three types of conflict together, and we explore the propensity to initiate, or not, legal action in at least one of these conflicts. It is important to mention here that the propensity to take legal action varies depending on the type of conflict, as respondents who experienced a conflict with employers or colleagues more frequently turned to the courts than those who experienced other types of conflict (see Table 2).

Table 2. Logistic regression on the probability of initiating at least one legal action

\begin{tabular}{|lll|}
\hline Characteristics & Estimation & Pr $>$ chi-2 \\
Intercept & -3.7391 & $<.0001$ \\
Type of conflict & & \\
$\begin{array}{l}\text { Conflict with employers or } \\
\text { colleagues }\end{array}$ & 0.4794 & $0.0287^{* *}$ \\
Conflict with a neighbor & Ref & Ref \\
Conflict with a private company as & & \\
consumers & -0.2367 & 0.4835 \\
First response & & \\
Doing nothing & -0.7016 & 0.4957 \\
Solving the conflict by themselves & Ref & Ref \\
Contacting a non-legal professional & 0.9875 & $<.0001^{* * *}$ \\
Contacting a legal professional & 2.9885 & $<.0001^{* * *}$ \\
Context of employment & & Ref \\
Private-sector employees & 0.3261 & $0.0463^{* *}$ \\
Public-sector employees & Ref & $0.0194^{* *}$ \\
Self-employed & 0.2813 & $0.0030^{* * *}$ \\
Unemployed & 0.1224 & 0.3519 \\
Age & & 0.9111 \\
Under 29 years & -0.7671 & \\
30 to 39 years & Ref & 0.1490 \\
40 to 49 years & 0.5135 & 0.6158 \\
50 to 59 years & 0.7768 & \\
Over 60 years & & \\
\hline
\end{tabular}

Source: PREFACE survey, "Pratiques et représentations face à l'État," January 2017 (ELIPSS/CDSP). 


\section{The decisive influence of contact with a legal intermediary}

All other things being equal, contact with a legal intermediary, who may be a legal professional or a non-legal professional, has a very significant impact on the decision to take the case to court. As expected, the probability of turning to the courts is the highest when respondents contacted a legal professional: $55 \%$ of conflicts in which respondents contacted a legal professional were taken to court. More importantly, our survey shows that getting advice from a non-legal professional is also significant. Conflicts that individual claimants first tried to resolve by turning to a non-legal professional are much more likely to be taken to court $(16 \%)$ than conflicts that respondents first tried to resolve by themselves $(4 \%)$ and, obviously, those in which respondents did nothing $(0 \%)$. These non-legal professionals may refer to different types of actors: in a conflict with an employer, it may be a union delegate or a work inspector; in a conflict with a neighbor, a local administration or non-profit organization; in a conflict with a private company, a consumer association or a mediator. In France, most of these intermediaries are not legal professionals, but they often have legal knowledge and expertise, and they are used to go to court. They thus usually consider the use of the law as a relevant tool for solving a conflict.

These figures show that contact with a non-legal professional, or even more significantly with a legal professional, is the most important step in the decision to take legal action. Knowing how to seek advice, how to choose the right intermediary, and how to adapt one's strategy according to the advice received are all factors that facilitate or impede use of the courts and, as a consequence, that amplify pre-existing social inequalities among plaintiffs.

\section{Figure 3. Probability of a conflict being taken to court}

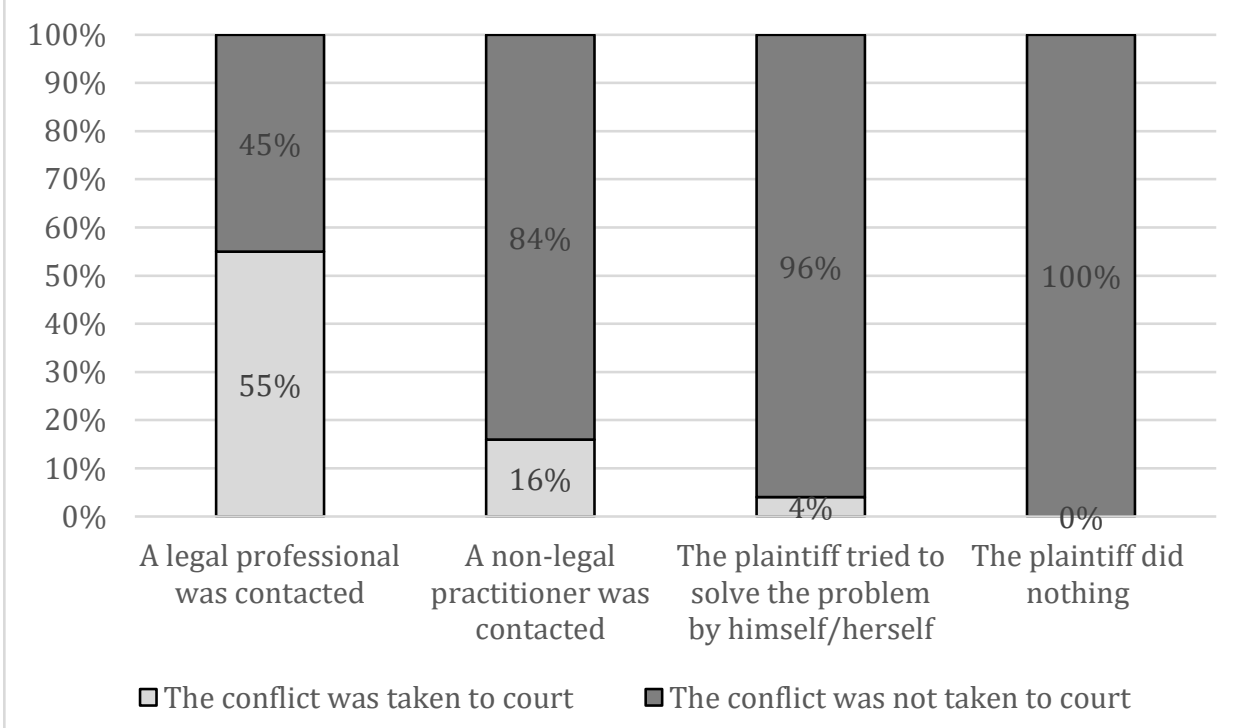

Source: PREFACE Survey, "Pratiques et représentations face à l'État," January 2017 (ELIPSS/CDSP). $\mathrm{N}=1,681$ (number of conflicts reported by respondents). 


\section{Negotiating a settlement or going to court? The influence of claimants' social characteristics}

The claimant's social characteristics may also affect the propensity to use the court system or to avoid it, independently of his or her contact with a legal intermediary. Three results of our survey are important in explaining the unequal propensity to go to court.

First, all other things being equal, context of employment significantly influences the decision to take legal action in all types of conflict. Private-sector employees who have experienced a conflict are more likely to go to court than public-sector employees (Table 2). To explain why being self-employed is not a significant variable, we can assume that the self-employed are those who are the most likely to turn to a legal professional and to negotiate a good settlement outside the courtroom, because they know that going to court is not necessarily the best way to defend one's interests. Significantly, as demonstrated in the next section, many self-employed people seek advice from a legal professional and obtain a satisfactory solution without going to court.

Second, another difference among respondents is based on age. Older respondents are more likely to turn to a legal intermediary and to resolve their conflicts in the courtroom than younger respondents. Besides the influence of contact with a legal intermediary, two main factors may explain their higher propensity to take legal action. On the one hand, older people have a better knowledge of the possibilities of legal actions due to a longer experience of conflicts. On the other hand, they feel more secure to litigate than younger respondents, who consider litigation as too costly in a context in which they occupy a temporary position in the labor market and live in temporary rental housing. The propensity to take legal action increases, all other things being equal, when respondents reach their thirties: when they have a more stable employment position, become owners of their property, and have more routinized relationships with private companies supplying goods and services, such as their bank or insurance provider.

Third, in contrast with the assessment made in many other studies on inequalities in access to the legal system, another important result of our survey is that income does not play a significant and direct role in using the courts. The wealthiest respondents do not turn more frequently to the courts than others.

These three results taken together suggest that lay people who experience a conflict have a third option, in addition to going to court or doing nothing: they can obtain satisfaction through an informal negotiation or a settlement. In some cases, those who turned to the courts were those who had no other option: they did not have the means to negotiate using the advice of a legal professional or could not negotiate a good settlement. We make the hypothesis that the best-advised and most skilled respondents were able to obtain satisfaction, both inside and outside the courtroom. To confirm this hypothesis, we will explore in the next section unequal satisfaction with the outcome of the conflict.

\subsection{Unequal satisfaction with the outcome of the conflict}

Inequalities among litigants are not limited to their unequal access to the civil justice system. Satisfaction with the outcome of the conflict is also a key element, whether the conflict was resolved through a trial or through an extralegal mechanism. Our analysis demonstrates three main dimensions of unequal satisfaction with the outcome.

First, satisfaction with the outcome of the conflict is higher among respondents who did not turn to the courts. Indeed, if we compare respondents' satisfaction with the outcome of the conflict, those who were the most satisfied are those who did not turn to the courts and who found an extralegal solution to their conflict. This result is important because it 
shows that going to court is not necessarily the best way to enforce one's rights: $49 \%$ of those who resolved their conflicts in court ${ }^{4}$ were satisfied with the outcome of their conflict, compared to $69 \%$ of those who resolved their conflict outside of court. Such a significant gap can probably be explained by two reasons. First, respondents who decided to turn to the courts spent money, time, and energy in their trial. Throughout this process, they nurtured higher expectations and hopes regarding the outcome of their trial than those who resolved their conflicts outside the courtroom. As a result, they are less likely to be satisfied with the decision because of their personal involvement in the conflict. Second, once they decided to take legal action, they gave the judge the power to make a decision to resolve their conflict and were no longer involved in its resolution. Thus, they were more likely to feel dispossessed of their conflict and the decision associated with it than those who negotiated a solution with the other party.

Second, contact with a legal intermediary influences satisfaction with the outcome, but not in the same way for all plaintiffs. If we focus only on respondents who contacted a legal professional, whether they turned to the courts or resolved their conflict outside of court, we observe that satisfaction with the outcome of the conflict seems to vary depending on context of employment. Although our sample of respondents who contacted a legal professional is too small to make general statements $(\mathrm{N}=122)$, it is relevant to highlight that $90 \%$ of the self-employed respondents who got in contact with a lawyer were satisfied with the outcome of the conflict, while this rate falls to $70 \%$ for private-sector employees and to $67 \%$ for public-sector employees. This difference suggests that contact with a legal professional does not influence the dispute process in the same way for all plaintiffs: the assistance of a lawyer seems more useful in obtaining satisfaction for the self-employed than for employees.

Third, satisfaction with the outcome of the conflict depends on plaintiffs' economic capital and, more precisely, on their income. The higher their household income, the more likely people are to be satisfied with the outcome of the conflict. Interestingly, we observe a more significant impact for litigated conflicts: income is a more determining factor in satisfaction with the outcome when the judge makes a decision than when a solution is found outside the courtroom. This result sheds light on the unequal experiences with the legal system (Spire \& Weidenfeld 2011): when people turn to the courts, the wealthiest respondents are much more likely to be satisfied with the legal decision than low-income respondents.

\section{Figure 4. Satisfaction with the outcome depending on monthly income}

\footnotetext{
${ }^{4}$ In this sample, we have excluded those who had to go to court as defendants.
} 


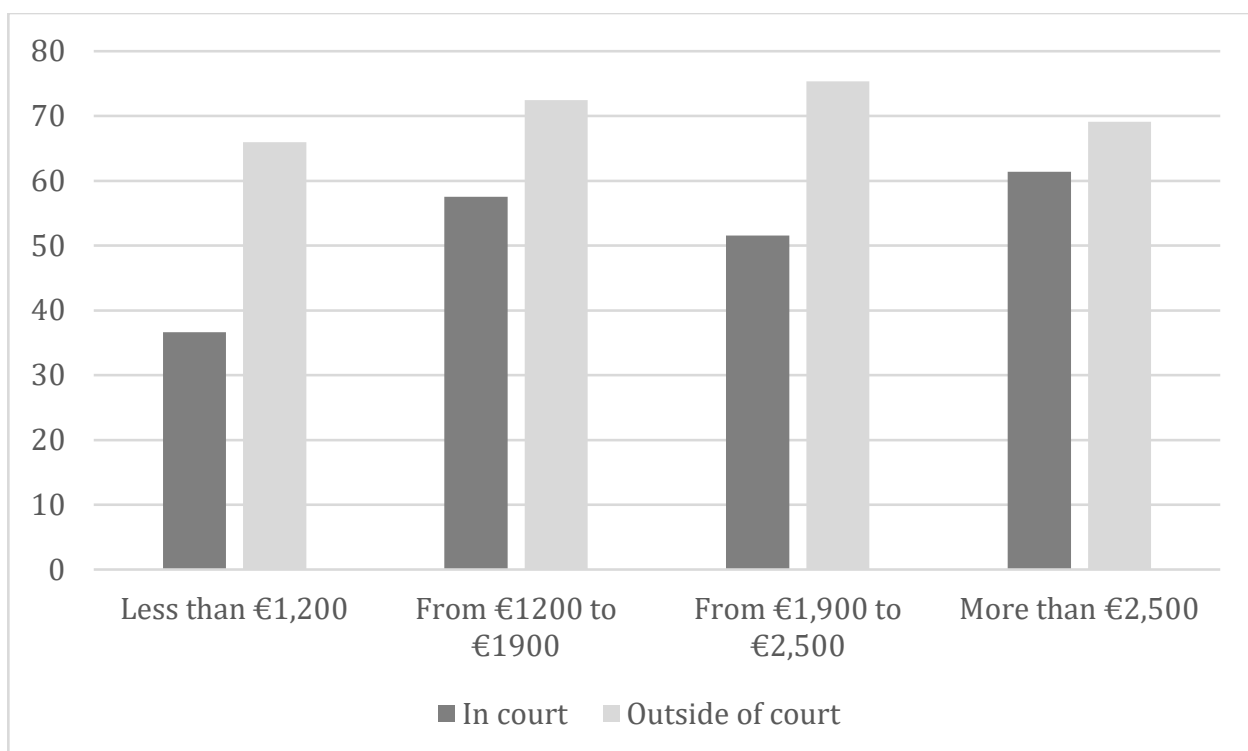

Source: PREFACE survey, "Pratiques et représentations face à l'État," January 2017 (ELIPSS/CDSP). Population: Respondents who have experienced at least one conflict $(\mathrm{N}=1,690)$

\section{DISCUSSION}

In this section, we will focus on two of our results that challenge or complement existing explanations of inequalities in access to the civil justice system. First, there are inequalities among plaintiffs at each stage of the dispute, and the contact with a legal intermediary significantly increases inequalities among plaintiffs. Second, further attention has to be paid to the differentiated role and influence of legal and non-legal professionals in France.

\subsection{The choice of legal intermediary creates inequalities among plaintiffs at each stage of the dispute pyramid}

Our quantitative data show that once a situation has been identified as an injustice, the type of legal intermediary contacted contributes to creating, or increasing, inequalities among respondents.

At the bottom of the pyramid, respondents view themselves as having more or less legitimacy to perceive an experience as an injury. Naming a conflict is always an early stage in a dispute and the statistical measure of this injurious experience is a way to "identify the social structure of disputing" (Felstiner et al. 1981: 636). For all types of conflict, the propensity to name an injurious experience as a conflict is higher among men than women; among those who have an MA or MS degree than among those without any qualifications; among those who live in urban areas than among those who live in rural areas; and among the oldest respondents than among the youngest. These results are particularly important because they allow us to better understand the social characteristics of those who do not experience conflicts or disagreements in any area of their lives. The respondents who do not name any injuries have been analyzed less by the literature on the dispute pyramid, primarily due to the methodological difficulties of getting access to this population. At the second level of the pyramid, the type of legal intermediary that people contact becomes a key factor that creates inequalities among those who have experienced a conflict. Depending on their occupational group, context of employment, and age, French 
people turn to different legal intermediaries. Indeed, small entrepreneurs and managerial self-employed, as well as older respondents, are more likely to turn to a legal intermediary, such as a lawyer, than other respondents. The link between social position and the use of a legal intermediary (e.g., a private lawyer) is a significant dimension of inequality before the law. At the third level of the pyramid, namely the decision to take legal action, the type of legal intermediary contacted reinforces inequalities among litigants: the likelihood of a conflict being taken to court is much higher if the legal intermediary contacted was a legal professional than if it was a non-legal professional.

In other words, these results show that social inequalities are cumulative and occur at each level of the dispute pyramid: at the point when people identify conflicts, when they decide to take an action, and when they turn to the civil legal system. More precisely, the role played by legal intermediaries varies depending on the social position of those who call upon them. On the one hand, respondents with a lower educational level, lower income, or a subordinate professional position are less likely to turn to a legal professional and to decide to take legal action than other respondents. On the other hand, even if they contact a legal professional and decide to take legal action, they are less likely to be satisfied by the outcome of the conflict.

Finally, our study's introduction into the dispute pyramid of the final stage of legal proceedings, that of obtaining satisfaction with the outcome, nuances the view, found in many sociolegal studies, that the courtroom is the best place to pursue and achieve rights (Felstiner et al. 1981: 654). Our study reveals that recourse to the law and the legal system does not necessary lead to a higher satisfaction rate than other methods of dispute resolution. It contradicts an implicit idea commonly shared within the sociolegal literature that going to court is the best way to redress situations of injustice. Satisfaction does not necessarily require taking the case to court but depends on the ability to choose the most efficient legal intermediary. The intervention of a legal intermediary plays a key role, both inside and outside the courtroom, and explains to a large extent why satisfaction with the outcome varies depending on social group.

Figure 5. Inequalities at each stage of the dispute pyramid

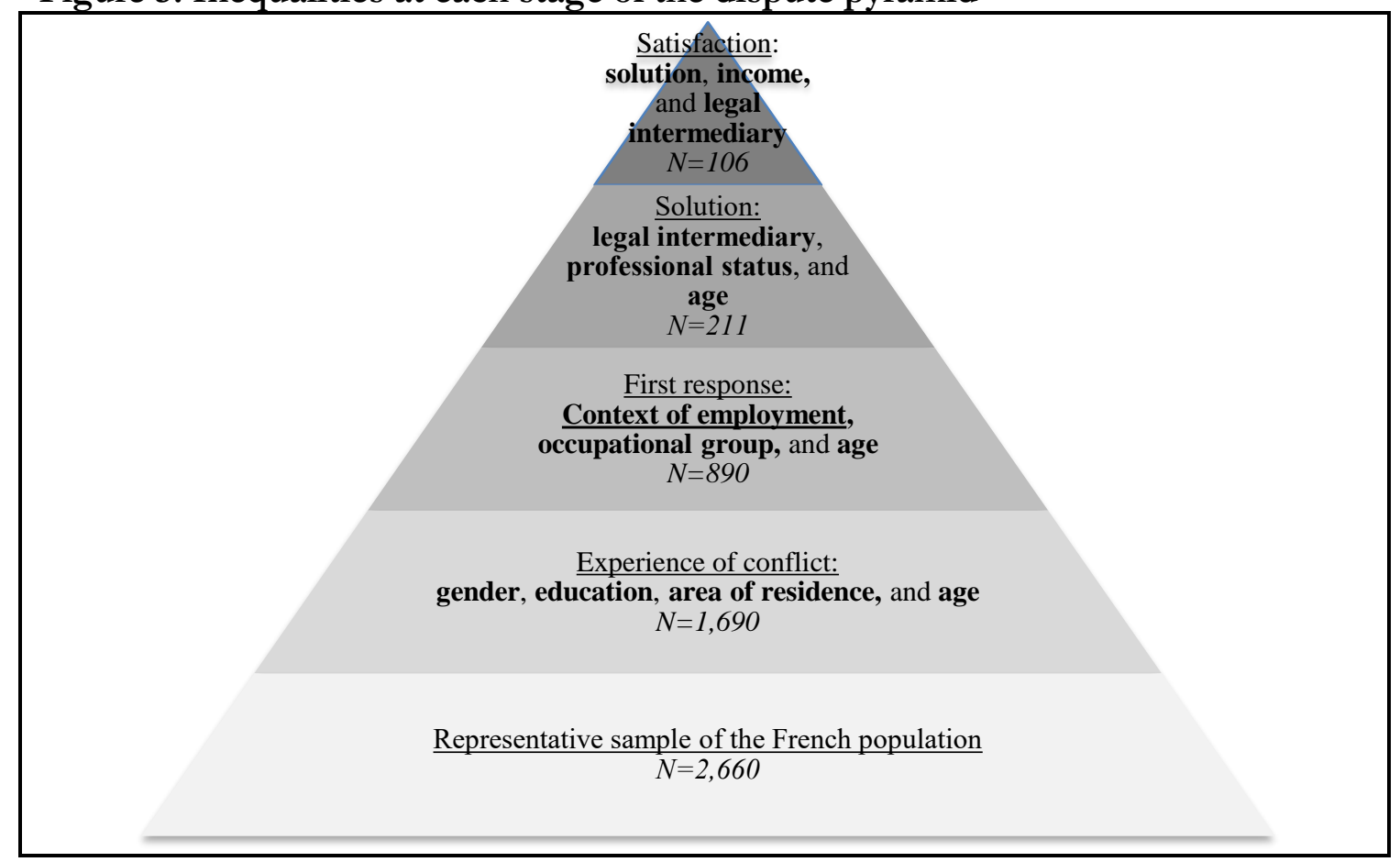


Source: PREFACE survey, “Pratiques et représentations face à l’État,” January 2017 (ELIPSS/CDSP).

Population: Respondents who answered the survey $(\mathrm{N}=2660)$

\subsection{The role of legal intermediaries in the French dispute process}

Although the sociolegal approach has increasingly influenced empirical research in France in recent years (Commaille 2015; Israël 2013), until now there has been no quantitative investigation that has tested the dispute pyramid model, originally developed in the United States, in the French context. Our survey on ordinary people's experiences of the civil legal system is the first study of this kind conducted in France.

Our analysis reveals that the dispute process takes different forms depending on the national context and, more precisely, on the characteristics of the legal system, of the role of legal intermediaries, and of the structure of social inequalities. In line with previous studies conducted in other countries (Blankenburg 1994; Genn 1999; Hertogh 2004), we have also observed that, in France, only a minority of disputes progress into becoming legal claims. However, the law does not affect ordinary French citizens' experiences of conflicts in the same way as it does in other national contexts. Three main specificities of the French context may explain the different role played by legal intermediaries.

First, people living in France who experience a conflict are much less likely to turn to a legal professional in comparison with people living in other countries. In France, legal professionals are conceived as possessing knowledge of the state, rather than as serving the needs of the population, as in the United States (García Villegas 2006: 369). In this context, the propensity to contact a legal professional when a conflict arises is relatively low in France, at around 7\% (according to the PREFACE survey). The small number of lawyers relative to the population, in comparison with other countries, reflects this specificity. Significantly, in 2016, there were only 93 lawyers per 100,000 inhabitants in France, compared to 147 for the same population in Belgium, 201 in Germany, 263 in Spain, and even 4,000 in the United States. ${ }^{5}$

Second, although the propensity to turn to a legal professional is low for the whole French population, there are significant inequalities in the probability of contacting a legal professional depending on the plaintiffs' social characteristics. Our study shows that unequal access to a legal professional is closely linked to social groups: respondents with a lower level of education, lower income, or a subordinate professional position are less likely to turn to a legal professional than others. Working-class and middle-class individuals do not usually use lawyers to advise them of their rights before a dispute arises (Abel 1989; Boigeol \& Willemez 2005); they usually get in contact with legal professionals after they have already made the decision to go to court (Salin 2020). This is not the case for managers and the self-employed, who frequently use legal professionals in the normal

\footnotetext{
${ }^{5}$ This gap has to be put in perspective: for instance, buying a house in the U.S. requires contacting a lawyer whereas in France there are other legal intermediaries - called notaries- who are entitled to play this role. Additionally, a significant proportion of US lawyers work to draft clauses aimed at preventing legal proceedings, whereas this activity to reduce litigation is less frequent in France. In Europe, Austria has a lower rate of lawyers per inhabitants than France, with 69 lawyers for 100,000 inhabitants. For Europe, data are produced by the Council of Bars and Law Societies of Europe (CCBE) are available at: https://www.ccbe.eu/fileadmin/speciality_distribution/public/documents/Statistics/EN_STAT_2016_Sta tistics_from_the_Observatory.pdf, accessed April 9, 2021. For the United States, data for 2018, produced by the American Bar Association National Lawyer Population Survey, available at: https://www.americanbar.org/about the aba/profession statistics/, accessed July 22, 2019.
} 
course of their work. This result can also be observed in other areas of law, such as in family civil justice cases, for which the inequalities between social groups are more significant than those related to gender (Bessière \& Gollac 2017). In comparison with the proliferation in the United States of public interest law firms and legal aid services that aim to assist claimants with low economic resources, in France lay people with few resources have only two options: hiring a private lawyer or contacting a non-legal professional. Those who meet the conditions to benefit from legal aid programs can turn to a private lawyer, but the majority will prefer to contact a non-legal professional. For instance, our study shows that after a conflict in the workplace, $56 \%$ of respondents contacted a non-legal professional, such as a union delegate or a work inspector.

More importantly, a third specificity of the French system is the institutional infrastructure of legal services that filter disputes at the pretrial stage (Blankenburg 1994). These institutions are unions, social services, or community legal services known as "Maisons de justice et du droit." They employ non-legal professionals who also assist plaintiffs. However, they do not influence the dispute process in the same way as the services provided by lawyers do. Indeed, our findings show that the propensity to take a conflict to court significantly increases if a lawyer was contacted. In France, non-legal professionals provide legal advice to people involved in legal proceedings who cannot afford a lawyer, but rarely encourage them to turn to the civil legal system. In other words, although the low number of lawyers in relation to the population is compensated for by the presence of these non-legal professionals, they do not play the same role. These non-legal professionals are more likely to filter plaintiffs out of the court system and to avoid civil litigation than legal professionals.

\section{CONCLUSION}

Based on a representative sample of the population, and tracing each stage of the conflict resolution process, this article has improved our understanding of the dispute pyramid in three ways. First, our research has shown how inequalities are produced and exacerbated at each stage of this process. Our results show that there are social inequalities among plaintiffs when people identify situations as conflicts; when they try to resolve the problem; when they decide to take their conflict to court; and when they obtain satisfaction from the court decision. Second, we showed that the type of legal intermediary that people contacted to resolve their conflict creates inequalities. The contact with a legal professional (e.g., a private lawyer) increases not only the propensity to turn to the courts but also the likelihood to obtain satisfaction with the outcome of the conflict. Third, our survey conducted in France reminds us that the observations made in the United States and in other countries concerning the conditions of access to the legal system are not universal and need to be adapted to the characteristics of each national context. In the case of France, when a conflict occurs, the choice to contact a legal professional is relatively rare because most people turn to non-legal professionals first. Our study demonstrates that inequalities before the civil legal system depend not only on unequal awareness of the law and legal procedures, but also on unequal contact with legal professionals and on the trust that ordinary people have in them. It would be relevant to broaden this analysis to other countries, in order to highlight how the experiences and representations of the legal system vary from one country to another, depending on the characteristics of the legal system, access to legal intermediaries, and the structure of inequalities. 


\section{REFERENCES}

Abel R L (1989) 'Comparative Sociology of Legal Professions' in Richard L. Abel and Philip S. C. Lewis (eds) Lawyers in Society: Comparative Theories. Berkley, CA: University of California Press, 80-153.

Albiston C (1999) The Rule of Law and the Litigation Process: The Paradox of Losing by Winning. Law \& Society Review 33(4), 869-910.

Albiston C, Edelman L and Milligan J (2014) The Dispute Tree and the Legal Forest. Annual Review of Law and Social Sciences 10, 105-31.

Bereni L (2007) French Feminists Renegotiate Republican Universalism: The Gender Parity Campaign. French Politics 5(3), 191-209.

Berrey E and Nielsen L B (2007) Rights of Inclusion: Integrating Identity at the Bottom of the Dispute Pyramid. Law and Social Inquiry 32(1), 233-60.

Bessière C and Gollac S (2017) Un entre-soi de possédant·es: Le genre des arrangements patrimoniaux dans les études notariales et cabinets d'avocat·es. Sociétés Contemporaines 108, 69-95.

Bessière C, Biland É, Bourguignon A , Gollac S, Mille M and Steinmetz H (2018) 'Faut sadapter aux cultures, Maitre!' La racialisation des publics de la justice familiale en France métropolitaine. Ethnologie française 169, 131-140.

Biland É (2019) Gouverner la vie privée: l'encadrement inégalitaire des séparations conjugales en France et au Québec. Lyon: ENS Éditions.

Billows S, Buchter L and Pélisse J (2019) 'Introduction: The Microfoundations of Legal Intermediation in Organizational Contexts' in Legal Intermediation. Bingley: Emerald Publishing.

Blankenburg E (1994) The Infrastructure for Avoiding Civil Litigation: Comparing Cultures of Legal Behavior in the Netherlands and West Germany. Law \& Society Review 28(4), 789-808.

Boigeol A and Willemez L (2005) 'Fighting for Survival: Unification, Differentiation and Representation of the French Bar' in William L. F. Felstiner (ed) Reorganisation and Resistance. Legal Professions Confront a Changing World. Oxford and Portland: Hart Publishing, 41-65.

Bourdieu P (1984 [1979]) Distinction: A Social Critique of the Judgement of Taste. Translated by Richard Nice. Cambridge: Harvard University Press.

Bourdieu P and Passeron J-C (1990) Reproduction in Education, Society and Culture. Thousand Oaks: SAGE Publications.

Bumiller K (1987) Victims in the Shadow of the Law: A Critique of the Model of Legal Protection. Signs 12(3), 421-39.

Carlin J E, Howard J and Messinger S L (1966) Civil Justice and the Poor: Issues for Sociological Research. Law \& Society Review 1(1), 9-90.

Chapman H and Frader L L (2004) Race in France: Interdisciplinary Perspectives on the Politics of Difference. Oxford and New York: Berghahn Books.

Chappe V-A and Keyhani N (2018) La fabrique d'un collectif judiciaire: La mobilisation 
des cheminots marocains contre les discriminations à la SNCF. Revue française de science politique 68(1), 7-29.

Clermont K M and Schwab S J (2004) How employment discrimination plaintiffs fare in federal court. Journal of Empirical Legal Studies 1(2), 429-458.

Collectif Onze (2013) Au tribunal des couples: Enquête sur des affaires familiales. Paris: Editions Odile Jacob.

Commaille J (2015) A quoi nous sert le droit? Paris: Gallimard.

Coulangeon P (2015) Social Mobility and Musical Tastes: A Reappraisal of the Social Meaning of Taste Eclecticism. Poetics 51, 54-68.

Curran B A (1977) The Legal Needs of the Public: The Final Report of a National Survey. Chicago: American Bar Foundation.

Davis S and Greenstein T (2009) Gender Ideology: Components, Predictors, and Consequences. Annual Review of Sociology 35, 87-105.

Engel D and Munger F (2003) Rights of Inclusion: Law and Identity in the Life Stories of Americans with Disabilities. Chicago, IL: University of Chicago Press.

Ewick P and Silbey S S (1998) The Common Place of Law: Stories from Everyday Life. Chicago, IL: University of Chicago Press.

Fassin D (2002) L'invention française de la discrimination. Revue française de science politique 52(4), 403-423.

Felstiner W L F, Abel R L and Sarat A (1981) The Emergence and Transformation of Disputes: Naming, Blaming, Claiming. . . Law \& Society Review 15(3/4), 631-54.

Galanter M (1974) Why the 'Haves' Come Out Ahead: Speculations on the Limits of Legal Change. Law \& Society Review 9(1), 95-160.

García Villegas M (2006) Comparative Sociology of Law: Legal Fields, Legal Scholarships, and Social Sciences in Europe and the United States. Law and Social Inquiry 31(2), 343-82.

Genn H (1999) Paths to Justice: What People Do and Think About Going to Law. Oxford and Portland, OR: Hart Publishing.

Greene S S (2016) Race, Class, and Access to Civil Justice. Iowa Law Review 101, 1234 322.

Guillaume C (2018a) When Trade Unions Turn to Litigation: 'Getting All the Ducks in a Row.' Industrial Relations Journal 49(3), 227-241.

Guillaume C (2018b) Syndiquées: Défendre les intérêts des femmes au travail. Paris: Presses de Sciences Po.

Hajjat A, Keyhani N and Cécile R (2019) Infraction raciste (non) confirmée: Sociologie du traitement judiciaire des infractions racistes dans trois tribunaux correctionnels. Revue française de science politique 69(3), 407-38.

Hertogh M (2004) A 'European' Conception of Legal Consciousness: Rediscovering Eugen Ehrlich. Journal of Law and Society 31(4), 457-81.

Hugrée C, Etienne P and Spire A (2015) Differences between Public and Private Sectors Employees Following the Managerial Turn in European States. Translated by 
Toby Matthews. Revue française de sociologie 56(1), 47-73.

Israël L (2013) Legalise it! The Rising Place of Law in French Sociology. International Journal of Law in Context 9(2), 262-78.

Kritzer H M (1990) The Justice Broker: Lawyers and Ordinary Litigation. Oxford: Oxford University Press.

Kritzer H (2008) To Lawyer or Not to Lawyer? Is that the Question? Journal of Empirical Legal Studies 5(4), 875-906.

Lejeune A and Orianne J-F (2014) The Construction of Workers' Rights Consciousness through Legal Intermediations: The Case of Employment Discrimination in Belgium. International Journal of Discrimination and the Law 14(4), 221-443.

Lejeune A and Ringelheim J (2019) Workers with disabilities between legal change and persisting exclusion: How contradictory rights shape legal mobilization. Law \& Society Review 53(4), 983-1015.

Marshall A-M (2005) Idle Rights: Employees' Rights Consciousness and the Construction of Sexual Harassment Policies. Law \& Society Review 39(1), 83-124.

Marshall A M and Barclay S (2003) In Their Own Words: How Ordinary People Construct the Legal World. Law \& Soc. Inquiry 28, 617-628.

Merry S E (1990) Getting Justice and Getting Even: Legal Consciousness among Working-Class Americans. Chicago: University of Chicago Press.

Miller R and Sarat A (1981) Grievances, Claims, and Disputes: Assessing the Adversary Culture. Law \& Society Review 15(3/4), 525-66.

Morrill C, Edelman L, Tyson K and Arum R (2010) Legal Mobilization in Schools: The Paradox of Rights and Race Among Youth. Law \& Society Review 44(3/4), 651-94.

Munger F and Engel D (1998) Civil Rights and Self-Concept: Life Stories of Law, Disability, and Employment. Droit et Cultures 35, 43-73.

Nielsen L B (2000) Situating Legal Consciousness: Experiences and Attitudes of Ordinary Citizens about Law and Street Harassment. Law \& Society Review 34(4), 105590.

Nielsen L B and Nelson R (2005) 'Scaling the Pyramid: A Sociolegal Model of Employment Discrimination Litigation' in Laura Beth Nielsen and Robert Nelson (eds) Handbook of Employment Discrimination Research: Rights and Realities 3-34. Dordrecht: Springer.

O'Barr W and Conley J (1988) Lay Expectations of the Civil Justice System. Law \& Society Review 22(1), 137-62.

Pélisse J (2017) Gérer les risques par le droit: Articulation et intermédiation dans les laboratoires de nanosciences en France et aux États-Unis. Droit et Société 96(2), 321-36.

Pélisse J (2019) Varieties of Legal Intermediaries: When Non-Legal Professionals Act as Legal Intermediaries. Studies in Law, Politics, and Society 81, 101-28.

Pinto L (1989) Du 'pépin' au litige de consommation. Actes de la recherche en sciences sociales 76(1), 65-81.

Pleasence P, Buck A, Balmer N, O'Grady A, Genn H and Smith M (2006) Causes of Action: Civil Law and Social Justice. Norwich: TSO. 
Pleasence P, Balmer N and Sandefur R L (2016) Apples and Oranges: An International Comparison of the Public's Experience of Justiciable Problems and the Methodological Issues Affecting Comparative Study. Journal of Empirical Legal Studies 13(1), 50-93.

Plessz M and Gojard S (2015) Fresh is Best? Social Position, Cooking, and Vegetable Consumption in France. Sociology 49(1), 172-190.

Revillard A (2017) La réception des politiques du handicap: Une approche par entretiens biographiques. Revue française de Sociologie 58(1), 71-95.

Salin F (2020) Inégalités sociales et judiciaires aux prud'hommes: le cas des référés. Droit et societe 3, 567-585.

Sandefur R (2008) Access to Civil Justice and Race, Class, and Gender Inequality. Annual Review of Sociology 34, 339-58.

Sarat A and Felstiner W L F (1989) Lawyers and Legal Consciousness: Law Talk in the Divorce Lawyer's Office. Yale Law Journal 98(8), 1663-88.

Sarat A (1990) '. . . The Law Is All Over': Power, Resistance and the Legal Consciousness of the Welfare Poor. Yale Journal of Law \& the Humanities 2(2), 343-79.

Savage M and Witz A (eds) (1992) Gender and Bureaucracy. Oxford and Cambridge: WileyBlackwell.

Spire A and Weidenfeld K (2011) Le tribunal administratif: une affaire d'initiés? Les inégalités d'accès à la justice et la distribution du capital procédural. Droit et Société $\mathbf{7 9}$, 689-713.

Spire A (2018) Résistances à l'impôt, attachement à l'Etat. Enquête sur les contribuables français. Paris: Le Seuil.

Talesh S (2015) Legal Intermediaries: How Insurance Companies Construct the Meaning of Compliance with Anti-Discrimination Laws. Law and Policy 37(3), 209-39.

Talesh S and Pélisse J (2019) How Legal Intermediaries Facilitate or Inhibit Social Change. Studies in Law, Politics, and Society 79, 111-45.

Taylor W K (2018) Ambivalent Legal Mobilization: Perceptions of Justice and the Use of the Tutela in Colombia. Law \& Society Review 52(2), 337-67.

Tyler T R (1988) What is Procedural Justice? Criteria used by Citizens to Assess the Fairness of Legal Procedures. Law \& Society Review 22(1), 103-36.

Willemez L (2005) 'A Political-Professional Commitment? French Workers' and Unions' Lawyers as Cause Lawyers' in Austin Sarat and Stuart Scheingold (eds) The Worlds Cause Lawyers Make: Structure and Agency in Legal Practice, 63-82. Stanford, CA: Stanford University Press. 